\title{
EFFECT OF WATER SALINITY AND POTASSIUM FERTILIZER LEVELS ON TOMATO PRODUCTIVITY AND WATER CONSUMPTION IN SIWA OASIS
}

\section{Zayton A. ${ }^{1}$; A. El-Shafei ${ }^{2}$; Kh. Allam ${ }^{1}$ and M. Mourad ${ }^{3}$ \\ ABSTRACT}

Effects of four irrigation water salinities; $E C_{i w}(1.25,2.5,5$ and $10 \mathrm{dS} / \mathrm{m})$ and four potassium fertilizer levels; $\mathrm{K}^{+}(0,40,80$ and $120 \mathrm{~kg} \mathrm{~K} 2 \mathrm{O} / \mathrm{fed})$ on yield and some quality parameters and water consumptive use; WCU of tomato grown under Siwa Oasis conditions were investigated. The splitplots design was carried out during the two successive growing seasons of 2003/04 and 2004/05. Yield, some quality parameters, water consumptive use and soil salinity data were inspected and subjected to proper statistical analysis and Maas and Hoffman threshold model. Water use efficiencies were also quantified. Results indicated that, the maximum total and marketable yield of 17.5 and $14.76 \mathrm{Mg} / \mathrm{fed}$, respectively was associated with the control treatment $\left(E C_{i w}=1.25 \mathrm{dS} / \mathrm{m}\right)$. Increasing the $E C_{i w}$, resulted in reducing the fruit number per plant, smaller fruit size and weight and consequently decreasing the total and marketable yield, increasing the fruits affected with blossom end rot (BER), higher total soluble solid content and decreasing the $\mathrm{pH}$ of the fruit juice were recorded. Increasing the $E C_{i w}$ led to decreasing both of water consumptive use and water use efficiencies. While, under moderate $E C_{i w}$ and high level of $\mathrm{K}^{+}$enhanced the plant growth parameters, total and marketable yield and water consumptive use and reduced the fruits affected with BER. However, the effect of the $E C_{i w}$ on the tested parameters was more pronounced than the effect of the $K^{+}$. The decrease of the total and marketable yield was performed to linear slope of 11.14 and $14.69 \%$ per $\mathrm{dS} / \mathrm{m}$ after the recorded threshold $\left(E C_{t}\right)$ value of 2.97 and $3.31 \mathrm{dS} / \mathrm{m}$, respectively. The decrease of tomato fruit yield with salinity was mostly owing to a linear decrease of the fruit weight of $9.8 \%$ per $d S / m$. Reduction of the fruit number with salinity of $5.5 \%$ per $\mathrm{dS} / \mathrm{m}$ made small contribution to reduced yield.

${ }^{1}$ Res. Ag. Eng., Res. Inst., Minis. Ag. \& Land Rec. Egypt.

${ }^{2}$ Asst. Prof., Ag. Eng. Dept., Fac. Ag., Alex. U.

${ }^{3}$ Prof. Agronomy, Alex. Ag. Exp. executive, ARC, Egypt. 
A logarithmic regression model was developed to express water consumptive use, WCU in $\mathrm{mm}$ as a relation with $E C_{i w}$ and $\mathrm{K}^{+}$. Results indicated an opposite relationship between tomato quality and quantity. Tomato plants in the control treatment averaged a higher WCU and WUE of $637 \mathrm{~mm}$ and $6.54 \mathrm{~kg} / \mathrm{m}^{3}$, respectively were compared with other treatments. Irrigation with saline water increased the soil salinity throughout the growing season and after harvesting .Overall increases were $0.613 \mathrm{dS} / \mathrm{m}$ of soil salinity for each $\mathrm{dS} / \mathrm{m}$ of $E C_{i w}$ during the growing season and $0.783 \mathrm{dS} / \mathrm{m}$ of final soil salinity for each $\mathrm{dS} / \mathrm{m}$ of $E C_{i w}$. Results confirmed that, $E C_{i w}$ up to $2.5 \mathrm{dS} / \mathrm{m}$ did not have major detrimental effects on marketable tomato yield. $\mathrm{K}^{+}$of $80 \mathrm{Kg} / f e d$ could mitigate the negative effects of salinity and enhance tomato productivity and decrease the percentage of fruits affected by BER in the Siwa environment.

Keywords: saline irrigated water, tomato, potassium fertilizer, yield, tomato quality, water efficiencies, soil salinity and Siwa Oasis.

\section{INTRODUCTION}

$\mathrm{T}$ The increasing demand for domestic, industrial, environmental and recreational water will force agriculturists to manage irrigation water carefully, contributing to environmental preservation. In parallel, brackish and saline water resources not used nowadays could be employed for irrigation if greater knowledge of salt tolerance and proper technology are developed. In applying saline water for irrigation, an integrated approach, which should account for soil, crop and water management at the same time should be adopted (Peterson, 1971). Tomato is moderately tolerant to salinity and could act as a model crop for saline water use because it is already cultivated in a few warm and rather dry areas where irrigation is essential for high yield. Natural soil hydrological processes in these regions frequently produce saline soils (Cuartero and Munoz, 1999). Crop management practices that enhance drought and salinity resistance, plant water use efficiency, plant growth and productivity would be beneficial under these circumstances. Several saline/brackish water irrigation researches were carried out on open culture tomatoes. The results evidently revealed that if suitable management practices were adapted, it is feasible to irrigate tomato using relatively high 
saline water under arid conditions. The tomato threshold; the electrical conductivity of saturated extract $\left(\mathrm{EC}_{\mathrm{e}}\right)$ above which yield starts to decline; is $2.5 \mathrm{dS} / \mathrm{m}$ and the reduction in the total fruit yield with increasing the salinity is $9.9 \%$ per $\mathrm{dS} / \mathrm{m}$ above threshold (Mass and Hoffman, 1977). Other threshold and rates of decrease have been attributed to different varieties and growth conditions (Dalton et al., 2001; Romero-Aranada et al., 2002; Agong et al., 2003 and Maggio et al., 2004). Cuartero and Munoz (1999) reported that salinity reduced tomato seed germination and lengthens the time needed for germination to such an extent that the establishment of a competitive crop by direct seeding would be difficult in soils where $\mathrm{EC}_{\mathrm{e}}$ was equal to or above $8 \mathrm{dS} / \mathrm{m}$. Romero-Aranda et al. (2002) mentioned that tomato seeds needs some 50\% additional days to germinate at $8 \mathrm{dS} / \mathrm{m}$ than in a medium without salt. Not all the seeds that fail to germinate in a highly saline medium, lose their viability. If the salt concentration is lowered, due to rainfall or irrigation with non-saline water, more than $50 \%$ of these seeds would still be capable of germination. They added that, priming seeds primed with $1 \mathrm{M} \mathrm{NaCl}$ for 36 hours seems advisable to establish a crop by direct sowing in saline soils, and seedling conditioning, either by exposure to moderately saline water exposure or by withholding watering until seedling wilt for 20-24 hours, can be recommended for crops that are to be established by transplanting. Snapp and Shennan (1992) mentioned that, salinity not only slows tomato root growth, but also increases the dead roots in those genotypes very sensitive to salt. Soria and Cuartero (1997) reported that, the root growth in tomato appears to be less affected by salt than shoot growth and so the root/shoot dry weight ratio is higher in plants grown under salt stress than in control plants, at all stages of development. They added that tomato plants grown with saline water have a significantly lower water uptake than those grown with fresh water. Cuartero and Munoz (1999) and Dorias et al. (2001) mentioned that $10 \%$ reduction in fruit weight is caused by irrigation with water has electrical conductivity; $\mathrm{EC}_{\mathrm{iw}}$ of $5-6 \mathrm{dS} / \mathrm{m}, 30 \%$ reduction with 8 $\mathrm{dS} / \mathrm{m}$ and about $40 \%$ at higher $\mathrm{EC}_{\mathrm{iw}}$. They added that tomato varieties which are to be grown under saline conditions must have notably bigger fruits in non-saline conditions in order to compensate for the weight loss that salty water will cause. Adams and Ho (1995) stated that several 
characteristics such as total soluble solids (TSS), sugars, acidity and $\mathrm{pH}$ are important quality parameters for both fresh and processing tomatoes, other characteristics such as taste and shelf life are more important only for the fresh market. TSS content is the most important quality criterion for tomato paste processing. TSS increases with salinity and hence the use of moderately saline irrigation water (3-6 dS/m) is recommended to improve fruit quality. However, special care must be taken when using saline water because salinity produces blossom end rot (BER) which makes fruits unacceptable for both the fresh market and the processing industry. Maggio and Barbieri (2004) reported that salinity reduced total plant water uptake and seemed to be a very important variable affecting total plant water uptake. They added that salinity of the irrigation water should be taken in account when calculating tomato water requirements. They worked on well fertilized plants and irrigated with non-saline water found that the lower limit of $\mathrm{EC}_{\mathrm{e}}$ at which yield starts to decline is higher than proposed by Maas and Hoffman and ranges from $1.6-3.1 \mathrm{dS} / \mathrm{m}$. This suggests an interaction between fertilization and tolerance to salt stress (Favaro-Blanco et al., 2003). Potassium; $\mathrm{K}^{+}$is the most prominent inorganic plant solute and as such makes a major contribution to lower the osmotic potential in the stele of roots that is a prerequisite for turgor pressure driven solute transport in xylem and water balance of plant. Adequate potassium fertilization of crop plants may facilitate osmotic adjustment, which maintains turgor pressure at lower leaf water potentials and can improve the ability of plants to tolerate drought and salinity stress (Lindhauer, 1985). Eakes et al. (1991) stated that adequate levels of potassium; $\mathrm{K}^{+}$nutrition enhanced drought and salinity resistance, water use efficiency, plant growth and productivity under drought and salinity conditions. Marschner (1995) mentioned that adequate potassium levels are essential for plants survival in saline habitats. Little information is available about the possibility of reducing the negative effects of irrigation water salinity by potassium applications and the influence of potassium fertilization levels and water quality on tomato growth and productivity. Therefore, the objectives of this study were to assess the effect of different salinity levels of irrigation water and potassium fertilization levels on the tomato yield and quality, water consumptive use and water use 
efficiencies. This information will enable the determination of EC threshold values according to Maas and Hoffman threshold model (1977) that optimize tomato fruit yield, quality and consequently growers' incomes in this region.

\section{MATERIALS AND METHODS}

\section{Field Experimental sites}

A field experiment was carried out and repeated during the two successive growing seasons of 2003/04 and 2004/05 at El-Kaf region represented newly reclaimed sandy soil in Siwa Oasis $\left(29^{\circ} 5^{\circ}-29^{\circ} 25^{\prime} \mathrm{N}\right.$ and longitude $25^{\circ} 8-26^{\circ} 5$ E). Four irrigation treatments and four different potassium application levels were applied to asses the response of tomato to irrigation with saline water and to test the hypothesis that salt stress may be mitigated by potassium fertilization. Before transplanting, soil samples were collected to a depth of $90 \mathrm{~cm}$ at $30 \mathrm{~cm}$ intervals to determine some physical properties. Electrical conductivity; $\mathrm{EC}_{\mathrm{e}}$ and $\mathrm{pH}$ were determined in 1:5 soil water suspensions and its extract. Soluble cations and anions were measured in the soil paste extracts that were prepared for each sample. Some soil characteristics were determined according to and Page (1982) at Nubaria Research Station and are summarized in Table 1 and 2.

Table 1. Some soil physical properties for the experimental site

\begin{tabular}{|c|c|c|c|c|c|c|c|c|c|c|}
\hline $\begin{array}{c}\text { Soil } \\
\text { depth } \\
(\mathrm{cm})\end{array}$ & \multicolumn{2}{|c|}{$\begin{array}{c}\text { Particle size } \\
\text { distribution }(\%)\end{array}$} & $\begin{array}{c}\text { Soil } \\
\text { texture } \\
\text { class }\end{array}$ & $\begin{array}{c}\text { SD } \\
\left(\mathrm{gcm}^{-3}\right)\end{array}$ & $\begin{array}{c}\theta_{\mathrm{s}} \\
\mathrm{m}^{3} \mathrm{~m}^{-3}\end{array}$ & $\begin{array}{c}\mathrm{PWP} \\
\mathrm{m}^{3} \mathrm{~m}^{-3}\end{array}$ & $\begin{array}{c}\mathrm{FC} \\
\mathrm{m}^{3} \mathrm{~m}^{-3}\end{array}$ & $\begin{array}{c}\mathrm{AW} \\
\mathrm{m}^{3} \mathrm{~m}^{-3}\end{array}$ & $\begin{array}{c}\mathrm{k}_{\mathrm{s}} \\
\mathrm{mm} \mathrm{h}^{-1}\end{array}$ \\
\hline $0-30$ & 94.4 & 4.7 & 0.9 & Sandy & 1.55 & 0.335 & 0.058 & 0.111 & 0.05 & 71.7 \\
$30-60$ & 94.1 & 4.8 & 1.1 & Sandy & 1.56 & 0.330 & 0.056 & 0.108 & 0.05 & 68.5 \\
$60-90$ & 95.0 & 3.9 & 1.1 & Sandy & 1.56 & 0.327 & 0.054 & 0.106 & 0.05 & 66.9 \\
\hline Aver. & 94.5 & 4.47 & 1.03 & Sandy & 1.56 & 0.331 & 0.056 & 0.108 & 0.05 & 69.0 \\
\hline
\end{tabular}

BD: bulk density, $\theta_{\mathrm{s}}$ : saturated moisture content, PWP: permanent welting point, FC:field capacity, AW: available water and $\mathrm{k}_{\mathrm{s}}$ : saturated hydraulic conductivity.

Table 2. Some soil chemical properties for the experimental site

\begin{tabular}{|c|c|c|c|c|c|c|c|c|c|c|c|c|}
\hline $\begin{array}{c}\text { Soil } \\
\text { depth }\end{array}$ & $\begin{array}{c}\mathrm{EC}_{\mathrm{e}} \\
\mathrm{dS} / \mathrm{m}\end{array}$ & $\mathrm{pH}$ & \multirow{2}{*}{$\mathrm{SAR}$} & $\mathrm{CaCO}_{3}$ & \multicolumn{3}{|c|}{ Soluble cations (meq/l) } & \multicolumn{3}{|c|}{ Soluble anions (meq/l) } \\
\cline { 6 - 15 } & & & $\mathrm{Ca}^{2+}$ & $\mathrm{Mg}^{2+}$ & $\mathrm{Na}^{+}$ & $\mathrm{K}^{+}$ & $\mathrm{CO}_{3}^{2-}$ & $\mathrm{HCO}_{3}{ }^{-}$ & $\mathrm{SO}_{4}{ }^{2-}$ & $\mathrm{Cl}^{-}$ \\
\hline $0-30 \mathrm{~cm}$ & 3.19 & 8.33 & 10.39 & 7.65 & 3.01 & 5.96 & 22.0 & 0.89 & - & 5.35 & 9.1 & 17.80 \\
$30-60 \mathrm{~cm}$ & 2.75 & 8.28 & 8.81 & 6.88 & 2.13 & 5.85 & 17.6 & 0.90 & - & 3.95 & 7.9 & 15.25 \\
$60-90 \mathrm{~cm}$ & 2.33 & 8.20 & 8.07 & 6.11 & 2.11 & 4.70 & 14.9 & 0.85 & - & 3.69 & 6.5 & 12.73 \\
\hline Aver. & 2.76 & 8.27 & 9.09 & 6.88 & 2.42 & 5.50 & 18.2 & 0.88 & - & 4.33 & 7.8 & 15.26 \\
\hline
\end{tabular}


Soil salinity was monitored three times; before sown, during the growing season and after harvesting to a depth of $90 \mathrm{~cm}$ at $30 \mathrm{~cm}$ intervals.

\section{Field experiment}

Tomato variety of Floradade was sown in the nursery at July 10, 2003 and July 17, 2004, respectively. Floradade is a cultivar recommended for open field cultivation with saline water. During the seed bed preparation, Organic manure with rate of $30 \mathrm{~m}^{3} / \mathrm{fed}$ was well mixed with super phosphate $\left(15.5 \% \mathrm{P}_{2} \mathrm{O}_{5}\right)$ with rate of $31 \mathrm{~kg} \mathrm{P}_{2} \mathrm{O}_{5} /$ fed. Seedlings were transplanted to the experimental plots at August 25, 2003 and August 30, 2004, respectively at $0.3 \mathrm{~m}$ within rows and $0.8 \mathrm{~m}$ between rows. The experimental area was plowed, leveled and divided into 3 areas (to represent the replications) and each area was divided into 16 plots. Each plot area was about $20 \mathrm{~m}^{2}(5 \mathrm{~m} \times 4 \mathrm{~m})$. It was contained five rows with spacing of $0.8 \mathrm{~m}$ and distance of $5 \mathrm{~m}$. Each plot was bounded by $1 \mathrm{~m}$ dikes to avoid the interference effect. All plots received a uniform application of $120 \mathrm{~kg} / \mathrm{fed}$ nitrogen fertilizer as ammonium nitrate $\left(33.5 \% \mathrm{NH}_{4} \mathrm{O}_{3}\right)$ spitted three equal doses added at 30, 70 and 90 days after transplanting. The experimental site was irrigated using surface irrigation system, which is the common irrigation system used in Siwa Oasis. Prior to planting and 30 days after transplanting the whole experimental plots were irrigated with good quality water form Dakrory deep well of $1.25 \mathrm{dS} / \mathrm{m}$ to ensure tomato seedling surviving and good plant establishment.

The statistical split plot design with three replications was adopted. Where, two variables were considered in the analysis. The main plots represented by four salinity levels of irrigation water; $\mathrm{EC}_{\mathrm{iw}}$, namely $\mathrm{I}_{1}=1.25, \mathrm{I}_{2}=2.5$, $\mathrm{I}_{3}=5$ and $\mathrm{I}_{4}=10 \mathrm{dS} / \mathrm{m}$. Those were prepared by mixing of highly saline drainage water and good quality well water at appropriate ratio to obtain the desired $\mathrm{EC}_{\mathrm{iw}}$. The chemical properties of the irrigation water treatments were represent in Table 3. The sub-plots were incorporated by four potassium application levels, namely $\mathrm{K}_{0}=0, \mathrm{~K}_{40}=40, \mathrm{~K}_{80}=80$ and $\mathrm{K}_{120}=120 \mathrm{~kg} \mathrm{~K} \mathrm{~K}_{2} \mathrm{O} / \mathrm{fed}$. Those were spitted by four equal doses of potassium sulphate $\left(\mathrm{K}_{2} \mathrm{SO}_{4}, 48 \% \mathrm{~K}_{2} \mathrm{O}\right)$ during the seed bed preparation, 20, 40 and 70 days after transplanting. All treatments were fully randomized within each of three replicates. The treatment of $\mathrm{I}_{1} \mathrm{~K}_{0}$; irrigation water salinity; $\mathrm{EC}_{\mathrm{iw}}$ of $1.25 \mathrm{dS} / \mathrm{m}$ and potassium application of 0 
$\mathrm{kg} \mathrm{K}_{2} \mathrm{O} /$ fed was represented the control treatment. All pesticides and herbicidal treatment were applied as recommended.

Table 3. Chemical properties of the irrigation water treatments.

\begin{tabular}{|c|c|l|r|r|r|r|r|r|r|c|}
\hline \multirow{2}{*}{$\begin{array}{c}\text { Treat- } \\
\text { ment }\end{array}$} & \multirow{2}{*}{$\begin{array}{c}\text { EC } \\
\text { dS/m }\end{array}$} & \multirow{2}{*}{$\mathrm{pH}$} & \multirow{2}{*}{$\mathrm{SAR}$} & \multicolumn{3}{|c|}{ Soluble cations (meq/l) } & \multicolumn{3}{|c|}{ Soluble anions (meq/l) } \\
\cline { 5 - 10 } & & & $\mathrm{Ca}^{2+}$ & $\mathrm{Mg}^{2+}$ & $\mathrm{Na}^{+}$ & \multicolumn{1}{c|}{$\mathrm{K}^{+}$} & $\mathrm{HCO}_{3}^{-}$ & $\mathrm{Cl}^{-}$ & $\mathrm{SO}_{4}{ }^{2-}$ \\
\hline $\mathrm{I}_{1}$ & 1.25 & 7.4 & 1.57 & 8.2 & 6.2 & 4.3 & 0.35 & 6.5 & 3.4 & 1.6 \\
$\mathrm{I}_{2}$ & 2.5 & 8.25 & 3.63 & 8.4 & 6.7 & 10.0 & 0.81 & 6.85 & 10.85 & 7.5 \\
$\mathrm{I}_{3}$ & 5.0 & 8.51 & 8.55 & 11.8 & 8.8 & 27.5 & 1.36 & 8.36 & 17.1 & 23.9 \\
$\mathrm{I}_{4}$ & 10.0 & 8.65 & 13.50 & 20.1 & 15.8 & 57.2 & 6.65 & 21.4 & 29.6 & 49.9 \\
\hline
\end{tabular}

Surplus irrigation water was added to provide a leaching fraction; LR according to Ayers and Westcot (1985) as follows:

$$
L R=\frac{E C_{i w}}{5 E C_{e}-E C_{i w}}
$$

where: LR: the leaching requirement to keep soil salinity within tolerable limits for crop production, $\mathrm{EC}_{\mathrm{iw}}$ : the electrical conductivity of irrigation water $(\mathrm{dS} / \mathrm{m})$ and $\mathrm{EC}_{\mathrm{e}}$ : the $\mathrm{EC}$ of the soil saturation extract for tomato crop appropriate to the tolerable degree of yield depression as defined by Maas and Hoffman (1977).

\section{Water consumptive use; WCU}

Soil samples were taken from different soil depths before and after each irrigation time to determine water consumptive use through the interval irrigation time, $\mathrm{WCU}_{\mathrm{m}}$ in $\mathrm{mm}$ according to Israelsen and Hansen (1962) as:

$$
W C U_{m}=\sum_{i=1}^{n} \frac{M_{a i}-M_{b i}}{100} \times \gamma_{s i} \times z_{i}
$$

where: m: the irrigation No., i: the soil layer No., n: the soil layer numbers, $\mathrm{M}_{\mathrm{ai}}$ and $\mathrm{M}_{\mathrm{bi}}$ : represent the soil moisture content (\%) after irrigation by $24 \mathrm{~h}$ and before the next irrigation immediately for layer i, $\gamma_{\text {si: }}$ : the specific bulk density of soil layer, and $\mathrm{z}_{\mathrm{i}}$ : depth of the soil layer. The three layer (0-30, $30-60$ and $60-90 \mathrm{~cm}$ ) were taken to represent the effective root zone. Seasonal water consumptive use; WCU was calculated from the sum of $\mathrm{WCU}_{\mathrm{m}}$ for all irrigation times.

\section{Applied irrigation water; AIW}

For each irrigation time, the amount of the applied irrigation water; AIW $_{m}$ was calculated according to the following equation 


$$
A I W_{m}=\frac{W C U_{m}}{E_{a}^{*}(1-L F)}
$$

where: $\mathrm{E}_{\mathrm{a}}{ }^{*}$ : designed water application efficiency, which was 0.7 .

Irrigation water for each plot was applied using $800 \mathrm{~mm}$ length and $70 \mathrm{~mm}$ in diameter P.V.C. spiles. The calibration of the spiles was carried out under the operation conditions using volume and time method. Seasonal applied irrigation water; AIW was calculated from the sum of $\mathrm{AIW}_{\mathrm{m}}$.

\section{Tomato yield and quality parameters}

Harvesting season was started at 104 and 110 days after transplanting for the first and second season, respectively. Total fruit yield; T Yield, marketable yield; $M$ Yield (the non-marketable yield included yellow fruits and fruits having blossom end rot; BER), the number of fruit per plant; FN/plant and the average weight of the fruit per plant; FW were determined. To evaluate the physical quality aspects of the tomato fruits, fruit height; FH and fruit diameter; FD were measured, while to evaluate the chemical quality aspects the total soluble solid content; TSS and the $\mathrm{pH}$ values of the fruit juice were determined.

\section{Irrigation water efficiencies}

Irrigation water used efficiency; IWUE was calculated as a ratio between the total fresh yield; FY and seasonal applied irrigation water; AIW (Michael, 1978). While, water used efficiency; WUE was calculated as a ratio between the total fresh yield; FY and seasonal water consumptive use; WCU (Jensen, 1983).

\section{Plant growth and productivity response to salinity}

Plant growth and productivity response to salinity was evaluated according to the threshold-slop model as described by Maas and Hoffman (1977) as:

$$
\text { R.Y }=100-S\left(E C_{e}-E C_{t}\right)
$$

where: RY: relative yield (\%), $\mathrm{S}$ : the percent yield decrease per unit salinity increase above the threshold, $\mathrm{EC}_{\mathrm{t}}$ : threshold (maximum root zone salinity without yield reduction) and $\mathrm{EC}_{\mathrm{e}}$ : average root zone soil salinity.

\section{Statistical analysis:}

The data obtained from the two growing seasons were subjected to proper statistical analysis using CoHort Software (2005). The treatment's means were compared using the least significant difference test (LSD) at 5\% probability level. Water consumptive use was considered in the analysis. 


\section{RESULTS AND DISCUSSION}

The effect of irrigation water salinity; $\mathrm{EC}_{\mathrm{iw}}$ and potassium fertilizer levels; $\mathrm{K}^{+}$on some tomato growth and productivity parameters as was investigated as follows:

\section{Number of fruit per plant; FN}

Results of the average number of fruit per plant (FN) for the two growing season are given in Table (4). The obtained results show significant differences in the average FN values among the treatments. The maximum FN of 56 was recorded in $\mathrm{I}_{1}$ treatment followed by $\mathrm{I}_{2}, \mathrm{I}_{3}$ and $\mathrm{I}_{4}$ treatments, respectively. Increasing the $\mathrm{EC}_{\mathrm{iw}}$ form $1.25 \mathrm{dS} / \mathrm{m}$ to $2.5,5$ and $10 \mathrm{dS} / \mathrm{m}$ led to decreasing the FN by about $8.9,21.4$ and $30.4 \%$, respectively. It means that the reduction of the fruit number with salinity was approximately $5.5 \%$ per $\mathrm{dS} / \mathrm{m}$. However, increasing the $\mathrm{K}^{+}$from 0.0 to 40,80 and 120 $\mathrm{kg} / \mathrm{fed}$ resulted in increasing the $\mathrm{FN}$ by about 9.8, 22 and $29.3 \%$, respectively. A significant interaction of $\mathrm{EC}_{\mathrm{iw}}$ and $\mathrm{K}^{+}$on the $\mathrm{FN}$ was noted. $\mathrm{I}_{1} \mathrm{~K}_{120}$ treatment had the maximum $\mathrm{FN}$ of 63 followed by $\mathrm{I}_{1} \mathrm{~K}_{80}$, $\mathrm{I}_{2} \mathrm{~K}_{120}$ and $\mathrm{I}_{2} \mathrm{~K}_{80}$, respectively. $\mathrm{I}_{4} \mathrm{~K}_{0}$ had the minimum $\mathrm{FN}$ of 36 , about $23.4 \%$ less than the control treatment $\left(\mathrm{I}_{1} \mathrm{~K}_{0}\right)$. These results declared that the effect of $\mathrm{EC}_{\mathrm{iw}}$ levels on the $\mathrm{FN}$ was more pronounced than the effect of the $\mathrm{K}^{+}$treatments.

\section{Fruit size}

Fruit diameter (FD) and height (FH) were investigated and the results were presented in Table (4). The results show highly significant effect of the treatments on the fruit diameter and height. Increasing the salinity level of irrigation water $\left(\mathrm{EC}_{\mathrm{iw}}\right)$ strongly decreased these parameters. While, increasing the potassium fertilizer $\left(\mathrm{K}^{+}\right)$slightly enhanced these parameters. The maximum FD and FH values of 55.8 and $52 \mathrm{~mm}$, respectively were obtained with $\mathrm{I}_{1}$ treatment. Increasing the $\mathrm{EC}_{\mathrm{iw}}$ to 5 and $10 \mathrm{dS} / \mathrm{m}$ resulted in decreasing the FD and FH by about $16.59,29.15 \%$ and $15.38,27.88 \%$, respectively. In the other hand increasing the $\mathrm{K}^{+}$to 80 and $120 \mathrm{Kg} / \mathrm{fed}$ led to increase the FD and $\mathrm{FH}$ by about $9.3,11.48 \%$ and $8.14,11.05 \%$, respectively. A significant interaction of $\mathrm{EC}_{\mathrm{iw}}$ and $\mathrm{K}^{+}$on the $\mathrm{FD}$ and $\mathrm{FH}$ was noticed. $\mathrm{I}_{1} \mathrm{~K}_{120}$ treatment had the maximum $\mathrm{FD}$ and $\mathrm{FH}$ values of 59 and $55 \mathrm{~mm}$, respectively. While $\mathrm{I}_{4} \mathrm{k}_{0}$ had the minimum FD and $\mathrm{FH}$ values of 37 and $36 \mathrm{~mm}$, respectively. These results are in agreement with Satti 
and Lopez (1994) and disagree with those of Petersen and et al. (1998), who mentioned that $\mathrm{K}^{+}$did not have any effect on the fruit size for salt stressed tomato.

\section{Fruit production per plant}

Results of the average fruit weight per plant (FW) for the two growing seasons are given in Table (4). Data obtained pointed out a highly significant effect of the $\mathrm{EC}_{\mathrm{iw}}$ and $\mathrm{K}^{+}$treatments on the $\mathrm{FW}$. The high $\mathrm{EC}_{\mathrm{iw}}$ inhibited the fruit production and appeared considerable decrease in the FW. $\mathrm{I}_{1}$ treatment had the heights FW value of $1380.5 \mathrm{~g} /$ plant. Increasing the $\mathrm{EC}_{\mathrm{iw}}$ form 1.25 to $2.5,5$ and $10 \mathrm{dS} / \mathrm{m}$ decreased the $\mathrm{FW}$ by about 11.4 , 38.4 and $53.5 \%$, respectively. The data showed that a linear decrease of the fruit weight with $9.8 \%$ per $\mathrm{dS} / \mathrm{m}$. However, increasing the $\mathrm{K}^{+}$from 0.0 to 40,80 and $120 \mathrm{~kg} /$ fed resulted in increasing the $\mathrm{FW}$ by about $9.2,26.4$ and $32 \%$, respectively. These results demonstrate highly effect of $\mathrm{EC}_{\mathrm{iw}}$ on the FW than the $\mathrm{K}^{+}$. A significant interaction among the treatments was noted. $\mathrm{I}_{1} \mathrm{k}_{120}$ treatment had the maximum FW of $1586 \mathrm{~g} /$ plant followed by $\mathrm{I}_{1} \mathrm{~K}_{80}$ and $\mathrm{I}_{2} \mathrm{~K}_{120}$, respectively. While $\mathrm{I}_{4} \mathrm{~K}_{0}$ had the minimum $\mathrm{FW}$ value of $610 \mathrm{~g} /$ plant, about $46.8 \%$ less than the control treatment.

\section{Total yield; T.Yield and Marketable yield; M.Yield}

Data of the average total tomato yield (T.Yield) for the two growing seasons are presented in Table (4). Results clearly show highly influence of $\mathrm{EC}_{\mathrm{iw}}$ and $\mathrm{K}^{+}$treatments on tomato yields. Concerning the total tomato yield, $\mathrm{I}_{1}$ treatments had the highest average tomato yield of $17.5 \mathrm{Mg} / \mathrm{fed}$. Slightly decrease in the total yield of $6 \%$ was noticed by $I_{2}$ treatments. However, increasing the $\mathrm{EC}_{\mathrm{iw}}$ to 5 and $10 \mathrm{dS} / \mathrm{m}$ adversely affected the total yield by about 26.4 and $56.3 \%$, respectively. In the other side, increasing the $\mathrm{K}^{+}$enhanced the average total yield. Increasing the $\mathrm{K}^{+}$to 40 and 80 $\mathrm{kg} / \mathrm{fed}$ increased the average total yield by about 7.7 and $20.1 \%$, respectively. However, no significant differences were found between the total tomato yield of $\mathrm{K}_{80}$ and $\mathrm{K}_{120}$ treatments. These results demonstrate the highly effect of the $\mathrm{EC}_{\mathrm{iw}}$ on the tomato yields than the $\mathrm{K}^{+}$. A significant interaction of $\mathrm{EC}_{\mathrm{iw}}$ and $\mathrm{K}^{+}$on the average total yield was noticed. The maximum average total yield of $18.85 \mathrm{Mg} / \mathrm{fed}$ was obtained by $\mathrm{I}_{1} \mathrm{~K}_{80}$ treatment followed by $\mathrm{I}_{1} \mathrm{~K}_{120}, \mathrm{I}_{2} \mathrm{~K}_{120}$ and $\mathrm{I}_{2} \mathrm{~K}_{80}$ treatments, respectively. While, $\mathrm{I}_{4} \mathrm{~K}_{0}$ treatment had the minimum average total yield of 
7.2 Mg/fed. Regarding the marketable yield, $I_{1}$ and $I_{2}$ treatments had the maximum marketable yield of 14.76 and $14.55 \mathrm{Mg} / \mathrm{fed}$, respectively. Increasing the $\mathrm{EC}_{\mathrm{iw}}$ to 5 and $10 \mathrm{dS} / \mathrm{m}$ resulted in decreasing the average marketable yield by about 30.7 and $68.2 \%$, respectively. The percentage of the non-marketable yield was approximately about 15.7, 15, 20.6 and $38.7 \%$ by $\mathrm{I}_{1}, \mathrm{I}_{2}, \mathrm{I}_{3}$ and $\mathrm{I}_{4}$ treatments, respectively. Also, it seems from the results presented in Table (4) that the percentage of the marketable yield to the total yield was enhanced by increasing the $\mathrm{K}^{+}$except $\mathrm{K}_{120}$ treatments.

Table 4. Statistical analysis of some growth and productivity parameters of tomato as affected by different irrigation water salinity and potassium fertilizer levels.

\begin{tabular}{|c|c|c|c|c|c|c|}
\hline \multirow{2}{*}{ Treatments } & \multicolumn{5}{|c|}{ Growth and productivity tomato parameters } \\
\cline { 2 - 7 } & FN/plant & $\begin{array}{c}\text { FD } \\
\text { mm }\end{array}$ & $\begin{array}{c}\text { FH } \\
\text { mm }\end{array}$ & $\begin{array}{c}\text { FW/plant } \\
\text { g }\end{array}$ & $\begin{array}{c}\text { T.Yield } \\
\text { Mg/fed }\end{array}$ & $\begin{array}{c}\text { M.Yield } \\
\text { Mg/fed }\end{array}$ \\
\hline $\mathrm{I}_{1}$ & $56 \mathrm{a}$ & $55.8 \mathrm{a}$ & $52.0 \mathrm{a}$ & $1380.5 \mathrm{a}$ & $17.50 \mathrm{a}$ & $14.76 \mathrm{a}$ \\
$\mathrm{I}_{2}$ & $51 \mathrm{~b}$ & $53.0 \mathrm{~b}$ & $48.3 \mathrm{~b}$ & $1223.8 \mathrm{~b}$ & $16.45 \mathrm{~b}$ & $14.55 \mathrm{a}$ \\
$\mathrm{I}_{3}$ & $44 \mathrm{c}$ & $46.5 \mathrm{c}$ & $44.0 \mathrm{c}$ & $851.3 \mathrm{c}$ & $12.89 \mathrm{c}$ & $10.23 \mathrm{~b}$ \\
$\mathrm{I}_{4}$ & $39 \mathrm{~d}$ & $39.5 \mathrm{~d}$ & $37.5 \mathrm{~d}$ & $642.5 \mathrm{~d}$ & $7.65 \mathrm{~d}$ & $4.69 \mathrm{c}$ \\
\hline Significance L & $* * *$ & $* * *$ & $* * *$ & $* * *$ & $* * *$ & $* *$ \\
\hline $\mathrm{K}_{0}$ & $41 \mathrm{~d}$ & $45.75 \mathrm{~d}$ & $43 \mathrm{~d}$ & $876.5 \mathrm{~d}$ & $12.02 \mathrm{c}$ & $9.24 \mathrm{c}$ \\
$\mathrm{K}_{40}$ & $45 \mathrm{c}$ & $48 \mathrm{c}$ & $44.5 \mathrm{c}$ & $957.5 \mathrm{c}$ & $13.15 \mathrm{~b}$ & $10.7 \mathrm{~b}$ \\
$\mathrm{~K}_{80}$ & $50 \mathrm{~b}$ & $50 \mathrm{~b}$ & $46.5 \mathrm{~b}$ & $1107.5 \mathrm{~b}$ & $14.66 \mathrm{a}$ & $12.16 \mathrm{a}$ \\
$\mathrm{K}_{120}$ & $53 \mathrm{a}$ & $51 \mathrm{a}$ & $47.75 \mathrm{a}$ & $1156.5 \mathrm{a}$ & $14.72 \mathrm{a}$ & $12.13 \mathrm{a}$ \\
\hline Significance L & $* * *$ & $* * *$ & $* * *$ & $* * *$ & $* * *$ & $* *$ \\
\hline $\mathrm{I}_{1} \mathrm{~K}_{0}$ & 47 & 52 & 50 & 1146 & 15.65 & 12.65 \\
$\mathrm{I}_{1} \mathrm{~K}_{40}$ & 53 & 55 & 50 & 1280 & 16.75 & 14.30 \\
$\mathrm{I}_{1} \mathrm{~K}_{80}$ & 60 & 57 & 53 & 1510 & 18.85 & 16.20 \\
$\mathrm{I}_{1} \mathrm{~K}_{120}$ & 63 & 59 & 55 & 1586 & 18.73 & 15.90 \\
\hline $\mathrm{I}_{2} \mathrm{~K}_{0}$ & 43 & 50 & 46 & 980 & 14.00 & 11.35 \\
$\mathrm{I}_{2} \mathrm{~K}_{40}$ & 47 & 52 & 46 & 1065 & 15.60 & 14.25 \\
$\mathrm{I}_{2} \mathrm{~K}_{80}$ & 55 & 55 & 50 & 1385 & 18.00 & 16.35 \\
$\mathrm{I}_{2} \mathrm{~K}_{120}$ & 57 & 55 & 51 & 1465 & 18.20 & 16.25 \\
\hline $\mathrm{I}_{3} \mathrm{~K}_{0}$ & 38 & 44 & 40 & 770 & 11.22 & 9.10 \\
$\mathrm{I}_{3} \mathrm{~K}_{40}$ & 42 & 46 & 44 & 850 & 12.35 & 9.90 \\
$\mathrm{I}_{3} \mathrm{~K}_{80}$ & 46 & 47 & 45 & 885 & 13.90 & 10.80 \\
$\mathrm{I}_{3} \mathrm{~K}_{120}$ & 50 & 49 & 47 & 900 & 14.10 & 11.10 \\
\hline $\mathrm{I}_{4} \mathrm{~K}_{0}$ & 36 & 37 & 36 & 610 & 7.20 & 3.85 \\
$\mathrm{I}_{4} \mathrm{~K}_{40}$ & 38 & 39 & 38 & 635 & 7.65 & 4.35 \\
$\mathrm{I}_{4} \mathrm{~K}_{80}$ & 40 & 41 & 38 & 650 & 7.90 & 5.30 \\
$\mathrm{I}_{4} \mathrm{~K}_{120}$ & 43 & 41 & 38 & 675 & 7.85 & 5.25 \\
\hline Significance L & $* * *$ & $* * *$ & $* * *$ & $* * *$ & $* * *$ & $* * *$ \\
\hline
\end{tabular}

Means within each column followed by the same letter/s are insignificant at 0.05 level of probability, $*$ : significance at the 0.05 probability level, $* *$ : significance at the 0.01 probability level, and $* * *$ : significance at the 0.001 probability level. 
The increase in tomato yield in treatments of $I_{1}$ and $I_{2}$ treatments compared to the other treatments can be explained by the significant increase in fruit weight and numbers. In the other side, the reduction in tomato yield by $\mathrm{I}_{3}$ and $\mathrm{I}_{4}$ corresponds with a reduction in fruit weight and numbers as shown in Table (4). These results confirmed that, appropriate $\mathrm{EC}_{\mathrm{iw}}$ and $\mathrm{K}^{+}$ enhanced the growth and productivity of tomato plant and were consistent with those reported by Caruso and Postigliono (1993), who reported that marketable yield was high where low to moderate saline water was used.

\section{Fruits with blossom end rot; BER}

The presented results in Table (5) revealed that the Fruits with blossom end rot; BER was significantly affected by $\mathrm{EC}_{\mathrm{iw}}$ and $\mathrm{K}^{+}$treatments. $\mathrm{I}_{1}$ and $\mathrm{K}_{120}$ treatments had the smallest percentage of the fruits with BER of 7.13 and $12.01 \%$, respectively. Increasing the $\mathrm{EC}_{\mathrm{iw}}$ from 1.25 to $2.5,5$ and 10 $\mathrm{dS} / \mathrm{m}$ resulted in considerable increase the percentage of fruits with BER by about 29.6, 96.4 and $184 \%$, respectively. However, increasing the $\mathrm{K}^{+}$ from 0.0 to 40,80 , and $120 \mathrm{Kg} /$ fed led to decrease the BER values by about 3.3, 9.1 and $10.5 \%$, respectively. These results show highly effect of the $\mathrm{EC}_{\mathrm{iw}}$ on BER than the $\mathrm{K}^{+}$. A significant interaction of $\mathrm{EC}_{\mathrm{iw}}$ and $\mathrm{K}^{+}$on the BER was observed. $\mathrm{I}_{4} \mathrm{~K}_{0}$ treatment has the heights percentage of fruits with BER of $20.4 \%$, while $\mathrm{I}_{1} \mathrm{~K}_{120}$ treatment exhibited the lowest percentage of fruits with BER of $6.45 \%$.

\section{Total soluble solids; TSS}

Data of the TSS of tomato fruit juice as affected by $\mathrm{EC}_{\mathrm{iw}}$ and $\mathrm{K}^{+}$treatments were shown in Table (5). The obtained results show highly significant effect of the $\mathrm{EC}_{\mathrm{iw}}$ treatments on the TSS. Increasing $\mathrm{EC}_{\mathrm{iw}}$ strongly increased the TSS. However, the results clearly showed that the TSS was not significantly affected by $\mathrm{K}^{+}$treatments. The minimum TSS value of $5.12 \%$ was obtained by $\mathrm{I}_{1}$ treatments. Increasing the $\mathrm{EC}_{\mathrm{iw}}$ to 5 and 10 $\mathrm{dS} / \mathrm{m}$ increased the TSS values by about 48.4 and $98.2 \%$, respectively. These results confirmed that the TSS was strictly related to the $\mathrm{EC}_{\mathrm{iw}}$. The interaction effect of the $\mathrm{EC}_{\mathrm{iw}}$ and $\mathrm{K}^{+}$treatments on the TSS was not noticed. Also, these results indicated an opposite trend between tomato quality and quantity as shown in Fig. (1). Increasing tomato yield decreases TSS content. The highest TSS value of $10.2 \%$ resulted from $\mathrm{I}_{4}$ treatments, which produced the least tomato yield. This may be related to 
the available soil moisture. Under high available soil moisture the root may absorb more water resulted in an increase in the fruit weight and a reduction in the TSS due to the dilution by water.

Table 5: Statistical analysis the effect of different $\mathrm{EC}_{\mathrm{iw}}$ and different $\mathrm{K}^{+}$on tomato fruit quality; BER, TSS and pH juice, and WCU.

\begin{tabular}{|l|c|c|c|c|}
\hline \multirow{2}{*}{ Treatments } & \multicolumn{3}{|c|}{ tomato fruit quality } & \multirow{2}{*}{ WCU } \\
\cline { 2 - 4 } & BER $\%$ & TSS $\%$ & pH juice & mm \\
\hline $\mathrm{I}_{1}$ & $7.13 \mathrm{~d}$ & $5.12 \mathrm{~d}$ & $4.68 \mathrm{a}$ & $637 \mathrm{a}$ \\
$\mathrm{I}_{2}$ & $9.24 \mathrm{c}$ & $5.98 \mathrm{c}$ & $4.49 \mathrm{ab}$ & $610 \mathrm{~b}$ \\
$\mathrm{I}_{3}$ & $14.00 \mathrm{~b}$ & $7.60 \mathrm{~b}$ & $4.20 \mathrm{~b}$ & $529 \mathrm{c}$ \\
$\mathrm{I}_{4}$ & $20.25 \mathrm{a}$ & $10.15 \mathrm{a}$ & $3.76 \mathrm{c}$ & $458 \mathrm{~d}$ \\
\hline Significance $\mathrm{L}$ & $* * *$ & $* * *$ & $* *$ & $* * *$ \\
\hline $\mathrm{K}_{0}$ & $13.42 \mathrm{a}$ & $7.11 \mathrm{~b}$ & $4.48 \mathrm{a}$ & $534 \mathrm{c}$ \\
$\mathrm{K}_{40}$ & $12.98 \mathrm{~b}$ & $7.21 \mathrm{ab}$ & $4.24 \mathrm{ab}$ & $554 \mathrm{~b}$ \\
$\mathrm{~K}_{80}$ & $12.20 \mathrm{c}$ & $7.26 \mathrm{a}$ & $4.23 \mathrm{ab}$ & $568 \mathrm{ab}$ \\
$\mathrm{K}_{120}$ & $12.01 \mathrm{~d}$ & $7.27 \mathrm{a}$ & $4.19 \mathrm{~b}$ & $579 \mathrm{a}$ \\
\hline $\mathrm{Significance} \mathrm{L}$ & $* * *$ & $\mathrm{n} . \mathrm{s}$. & $\mathrm{n} . \mathrm{s}$. & $*$ \\
\hline $\mathrm{I}_{1} \mathrm{~K}_{0}$ & 7.90 & 5.00 & 4.55 & 610 \\
$\mathrm{I}_{1} \mathrm{~K}_{40}$ & 7.50 & 5.15 & 4.53 & 633 \\
$\mathrm{I}_{1} \mathrm{~K}_{80}$ & 6.66 & 5.17 & 4.52 & 645 \\
$\mathrm{I}_{1} \mathrm{~K}_{120}$ & 6.45 & 5.17 & 4.50 & 660 \\
\hline $\mathrm{I}_{2} \mathrm{~K}_{0}$ & 10.84 & 5.85 & 4.55 & 575 \\
$\mathrm{I}_{2} \mathrm{~K}_{40}$ & 10.10 & 5.95 & 4.53 & 610 \\
$\mathrm{I}_{2} \mathrm{~K}_{80}$ & 8.20 & 6.04 & 4.48 & 625 \\
$\mathrm{I}_{2} \mathrm{~K}_{120}$ & 7.80 & 6.08 & 4.40 & 630 \\
\hline $\mathrm{I}_{3} \mathrm{~K}_{0}$ & 14.50 & 7.55 & 4.33 & 510 \\
$\mathrm{I}_{3} \mathrm{~K}_{40}$ & 14.00 & 7.55 & 4.25 & 521 \\
$\mathrm{I}_{3} \mathrm{~K}_{80}$ & 13.80 & 7.63 & 4.20 & 535 \\
$\mathrm{I}_{3} \mathrm{~K}_{120}$ & 13.70 & 7.65 & 4.20 & 551 \\
\hline $\mathrm{I}_{4} \mathrm{~K}_{0}$ & 20.40 & 10.10 & 3.90 & 440 \\
$\mathrm{I}_{4} \mathrm{~K}_{40}$ & 20.35 & 10.12 & 3.78 & 452 \\
$\mathrm{I}_{4} \mathrm{~K}_{80}$ & 20.15 & 10.18 & 3.70 & 466 \\
$\mathrm{I}_{4} \mathrm{~K}_{120}$ & 20.10 & 10.20 & 3.64 & 474 \\
\hline $\mathrm{Significance} \mathrm{L}$ & $* * *$ & n.s. & n.s. & n.s. \\
\hline
\end{tabular}

Values are means of three replicates for each treatment over two years. Means within each column followed by the same letter/s are insignificant at 0.05 level of probability. n.s.: not significance at the 0.05 probability level, *: significance at the 0.05 probability level, **: significance at the 0.01 probability level, $* * *$ : significance at the 0.001 probability level.

\section{pH of fruit juice:}

Results of the $\mathrm{pH}$ of the tomato juice are given in Table (5). Results show significantly effect of $\mathrm{EC}_{\mathrm{iw}}$ treatments on the $\mathrm{pH}$ values. $\mathrm{I}_{1}$ treatment had 
the maximum $\mathrm{pH}$ value of 4.68 . Increasing the $\mathrm{EC}_{\mathrm{iw}}$ from 1.25 to $10 \mathrm{dS} / \mathrm{m}$ resulted in decreasing the $\mathrm{pH}$ value by about $19.5 \%$. However the $\mathrm{pH}$ of the tomato juice was not significantly affected by $\mathrm{K}^{+}$treatments. Also, the interaction effect of $\mathrm{EC}_{\mathrm{iw}}$ and $\mathrm{K}^{+}$treatments on the $\mathrm{pH}$ was not noted.

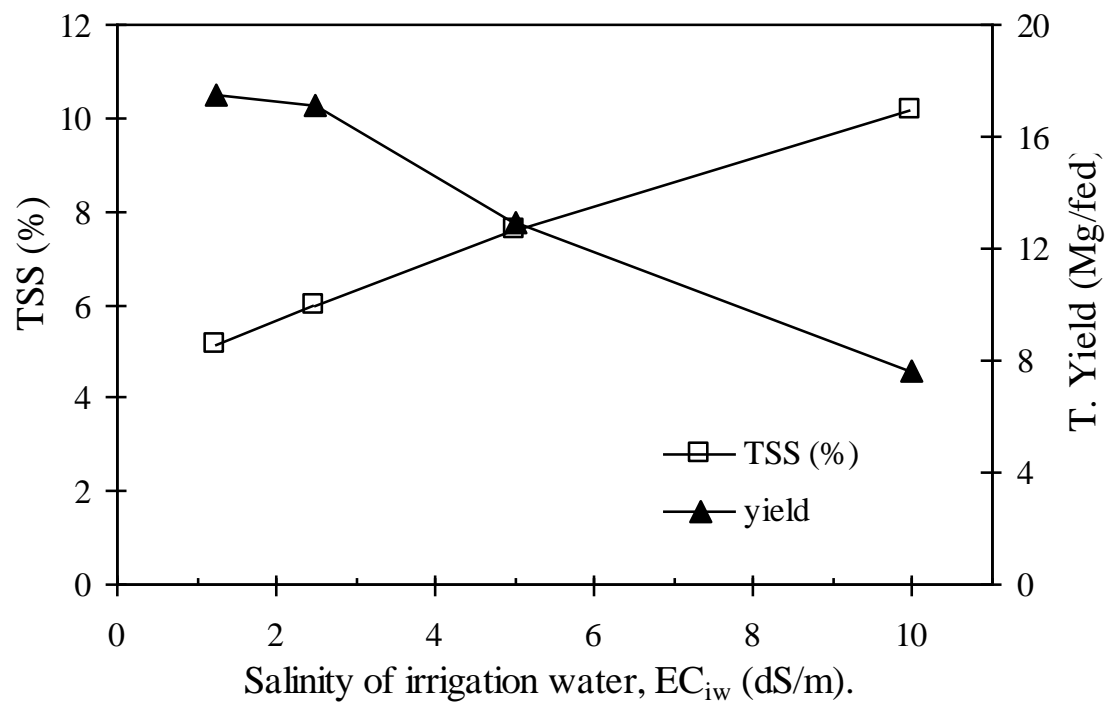

Fig. (1): Relationship between tomato fruit quantity and quality as affected by $\mathrm{EC}_{\mathrm{iw}}$.

\section{Water consumptive use, WCU}

Water consumptive use values based on the soil water depletion between two irrigation events and the corresponding average values of the total amount of applied irrigation water (AIW) were presented in Table (6). Also, the relationship between $\mathrm{WCU}$ and $\mathrm{EC}_{\mathrm{iw}}$ was illustrated in Fig. (2). Potassium fertilizer levels, $\mathrm{K}^{+}$have slightly effect on WCU, however WCU showed a strongly relation to salinity level. WCU decreased logarithmically as the $\mathrm{EC}_{\mathrm{iw}}$ increased. $\mathrm{I}_{1}$ treatments had the greatest WCU value of $637 \mathrm{~mm}$ followed by $\mathrm{I}_{2}$ treatments, while $\mathrm{I}_{4}$ treatments had the lowest WCU value of $458 \mathrm{~mm}$, which was less than the $\mathrm{I}_{1}$ treatments by about $28.10 \%$. However, WCU of $I_{2}$ and $I_{3}$ were less by about 4.24 and $16.95 \%$ compared to $I_{1}$ treatments. A logarithmic regression model was developed to express water consumptive use, WCU in $\mathrm{mm}$ as a relation with irrigation water salinity; $\mathrm{EC}_{\mathrm{iw}}$ in $\mathrm{dS} / \mathrm{m}$ and potassium fertilizer levels; $\mathrm{K}^{+}$in $\mathrm{kg} \mathrm{K} \mathrm{K}_{2} \mathrm{O} /$ fed as the following: 


$$
\mathrm{WCU}=644+0.35 \mathrm{~K}^{+}-88 \ln \left(\mathrm{EC}_{\mathrm{iw}}\right)
$$

With a correlation coefficient; $\mathrm{R}^{2}=0.9$

Based on the above mentioned results, salinity of irrigation water should be taken into account when calculating tomato water requirements.

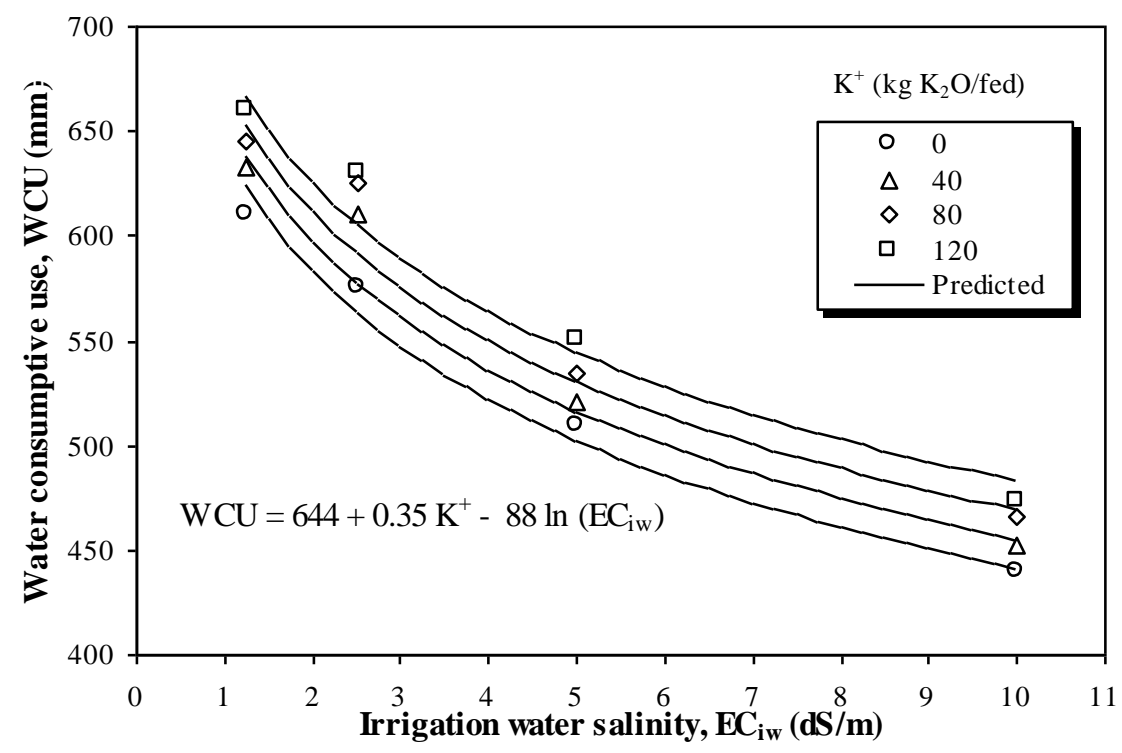

Fig. (2): Relationship between water consumptive use, WCU as affected by irrigation salinity; $\mathbf{E C}_{\mathrm{iw}}$ and potassium fertilizer; $\mathrm{K}^{+}$.

Water use efficiency; WUE and irrigation water use efficiency; IWUE Results of WUE as affected by $\mathrm{EC}_{\mathrm{iw}}$ were illustrated in Fig. (3) and Table (6). Tomato WUE decreased linearly as the $\mathrm{EC}_{\mathrm{iw}}$ increased. $\mathrm{I}_{1}$ treatments had the maximum WUE value of $6.54 \mathrm{Kg} / \mathrm{m}^{3}$ while $\mathrm{I}_{4}$ treatments had the lowest WUE value of $3.98 \mathrm{Kg} / \mathrm{m}^{3}$. The same trend was observed with IWUE. $\mathrm{I}_{1}$ treatments had the greatest IWUE of $4.05 \mathrm{~kg} / \mathrm{m}^{3}$ followed by $\mathrm{I}_{2}$ and $\mathrm{I}_{3}$, respectively. However, $\mathrm{I}_{4}$ treatments had the lowest IWUE value of $1.83 \mathrm{~kg} / \mathrm{m}^{3}$. The relationship between water use efficiency; WUE and irrigation water use efficiency; IWUE as affected by irrigation salinity; $\mathrm{EC}_{\mathrm{iw}}$ have been studied. The best correlation is shown in Fig. (3) as

$$
\mathrm{WUE}=-0.302 \mathrm{EC}_{\mathrm{iw}}+7.1 \quad \text { with } \mathrm{R}^{2}=0.9778
$$




$$
\text { IWUE }=-0.256 \mathrm{EC}_{\mathrm{iw}}+4.39 \quad \text { with } \mathrm{R}^{2}=0.9996
$$

Similar results have been reported by Al-Karaki (2000). While, RomeroAranda et al. (2002) mentioned that, the WUE and IWUE increased as the $\mathrm{EC}_{\mathrm{iw}}$ increased. This discrepancy could be attributed to the range of salinity tested, the environmental conditions under which plants have been growing and the cultivar used.

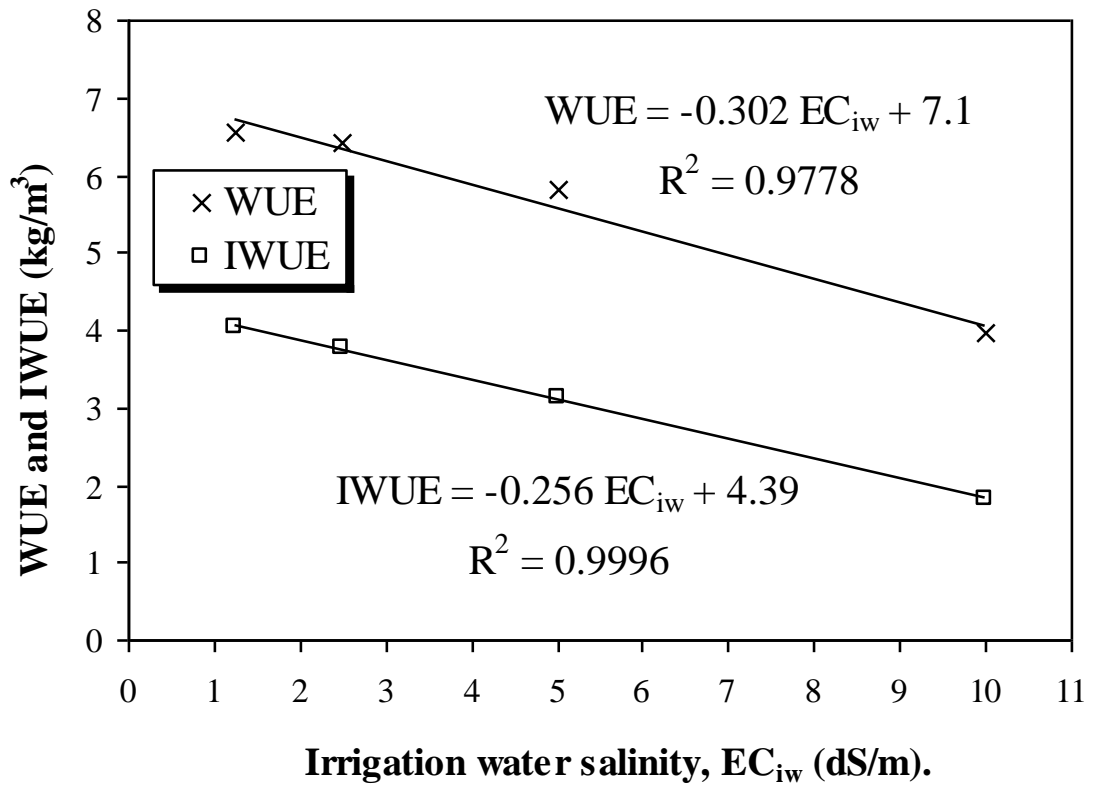

Fig. (3): Relationship between Water use efficiency; WUE and irrigation water use efficiency; IWUE as affected by irrigation salinity; ECiw.

Table .6: The effect of different $\mathrm{EC}_{\mathrm{iw}}$ on WCU, AIW, WUE and IWUE.

\begin{tabular}{|c|c|c|c|c|}
\hline Treatments & $\begin{array}{c}\text { WCU } \\
(\mathrm{mm})\end{array}$ & $\begin{array}{c}\text { AIW } \\
(\mathrm{mm})\end{array}$ & $\begin{array}{c}\text { WUE } \\
\left(\mathrm{kg} / \mathrm{m}^{3}\right)\end{array}$ & $\begin{array}{c}\text { IWUE } \\
\left(\mathrm{kg} / \mathrm{m}^{3}\right)\end{array}$ \\
\hline $\mathrm{I}_{1}$ & 637 & 1029 & 6.54 & 4.05 \\
$\mathrm{I}_{2}$ & 610 & 1036 & 6.42 & 3.78 \\
$\mathrm{I}_{3}$ & 529 & 983 & 5.80 & 3.12 \\
$\mathrm{I}_{4}$ & 458 & 997 & 3.98 & 1.83 \\
\hline
\end{tabular}




\section{Soil salinity; $\mathbf{E C}_{\mathbf{e}}$}

Fig. (4) represents the relationship between salinity level of irrigation water $\left(\mathrm{EC}_{\mathrm{iw}}\right)$ and soil salinity $\left(\mathrm{EC}_{\mathrm{e}}\right)$. Irrigation with saline water resulted in increased the soil salinity throughout the growing season and after harvesting. Overall increases were $0.613 \mathrm{dS} / \mathrm{m}$ of soil salinity for each $\mathrm{dS} / \mathrm{m}$ of $\mathrm{EC}_{\mathrm{iw}}$ during the growing season and $0.783 \mathrm{dS} / \mathrm{m}$ of final soil salinity for each $\mathrm{dS} / \mathrm{m}$ of $\mathrm{EC}_{\mathrm{iw}}$. The mean $\mathrm{EC}_{\mathrm{e}}$ values throughout the growing season and after harvesting with the soil depth as affected by different salinity levels of irrigation water were presented in Fig. (4).

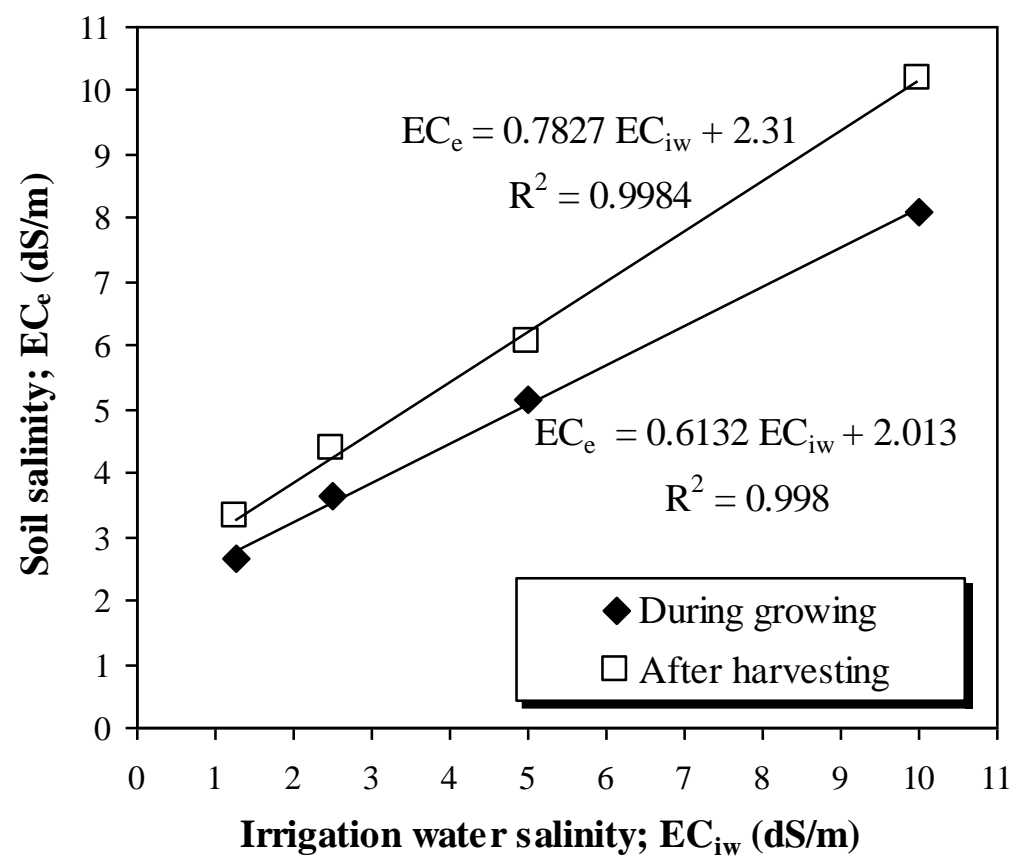

Fig.(4): Soil salinity; EC e as affected by irrigation water salinity; EC $C_{i w}$.

The relationship between Soil salinity; $\mathrm{EC}_{\mathrm{e}}$ as affected by irrigation water salinity; $\mathrm{EC}_{\mathrm{iw}}$ has been studied. The best correlation is shown in Fig. (4) as

During growing season:

$$
\mathrm{EC}_{\mathrm{e}}=0.6132 \mathrm{EC}_{\mathrm{iw}}+2.013 \quad \text { with } \mathrm{R}^{2}=0.998
$$

After harvesting:

$$
\mathrm{ECe}=0.7827 \mathrm{EC}_{\mathrm{iw}}+2.31 \quad \text { with } \mathrm{R}^{2}=0.9984
$$




\section{Salt accumulation and distribution}

Fig. (5) shows the soil salinity; $\mathrm{EC}_{\mathrm{e}}$ distribution with the soil depth as affected by different $\mathrm{EC}_{\mathrm{iw}}$ before sowing, during growing season and after harvesting. The $\mathrm{EC}_{\mathrm{e}}$ values before sowing was indicated by dotted line in. During the growing season, the $\mathrm{EC}_{\mathrm{e}}$ for $\mathrm{I}_{1}$ treatment was improved, while $\mathrm{EC}_{\mathrm{e}}$ values for $\mathrm{I}_{2}$ treatment were increased as compared with their values before sowing. The mean $\mathrm{EC}_{\mathrm{e}}$ values during the growing season ranged from 3.15 to $2.1 \mathrm{dS} / \mathrm{m}$ and from 4.10 to $3.20 \mathrm{dS} / \mathrm{m}$ for $I_{1}$ and $I_{2}$ treatments,

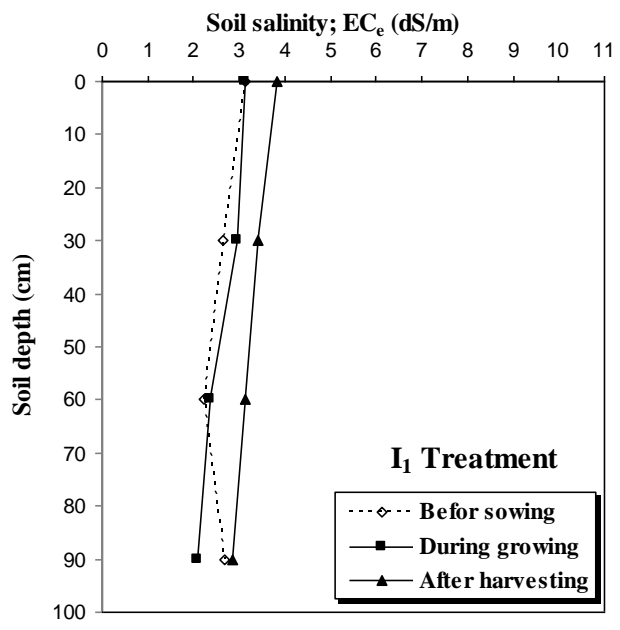

(a)

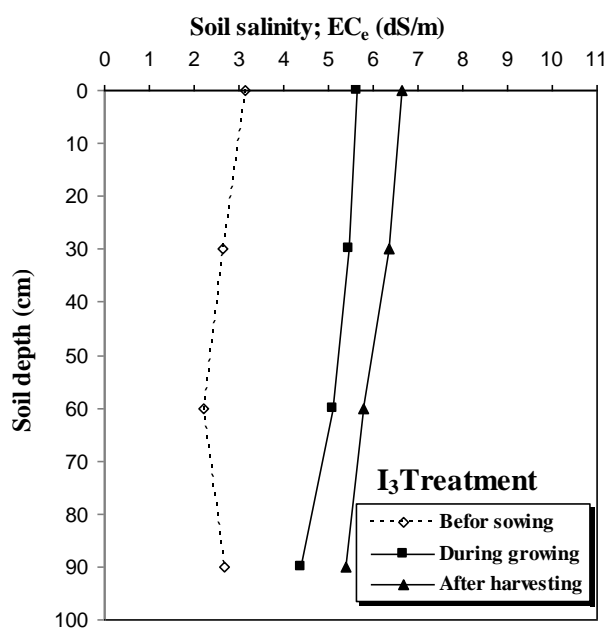

(c)

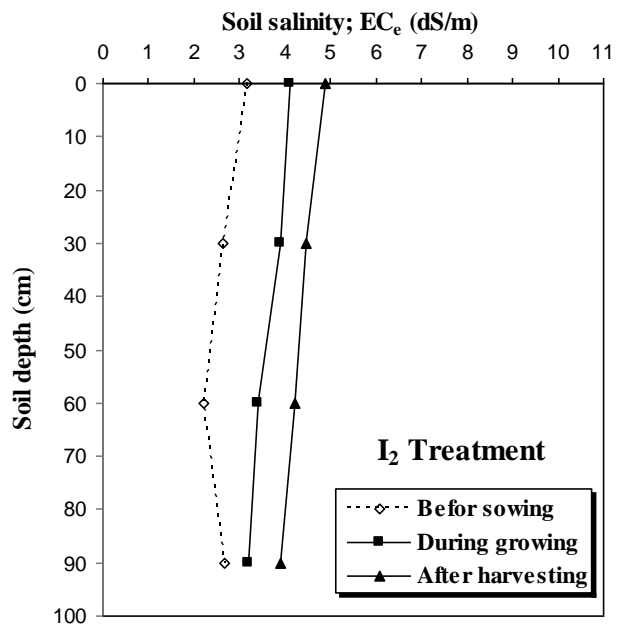

(b)

Soil salinity; $\mathrm{EC}_{\mathrm{e}}(\mathrm{dS} / \mathrm{m})$

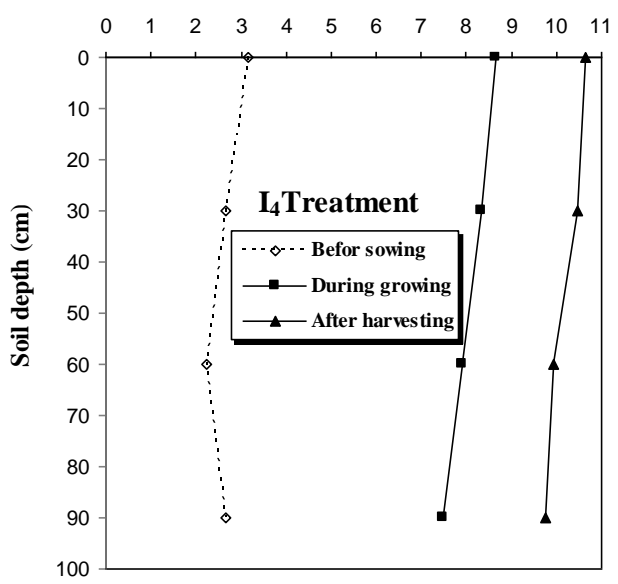

(d)

Fig. (5). Soil salinity; ECe profile as affected by different irrigation water salinity; $\mathbf{E C}_{\mathrm{iw}}$. 
respectively. Increasing the $\mathrm{EC}_{\mathrm{iw}}$ to 5 and $10 \mathrm{dS} / \mathrm{m}$ adversely affected the $\mathrm{EC}_{\mathrm{e}}$ that severely increased and showed different distribution throughout the soil profile according to the salinity level of irrigation water. The highest $\mathrm{EC}_{\mathrm{e}}$ mean value of 8.1 and $10.2 \mathrm{dS} / \mathrm{m}$ was measured with $\mathrm{I}_{4}$ treatment during the growing season and after harvesting, respectively. Application of Maas and Hoffman model on yield

Data of the total and marketable fruit yield in response to increasing salinity were analyzed using the Maas and Hoffman conceptual model. Relative total and marketable yield decreased linearly with increasing the soil salinity above the threshold value $\left(\mathrm{EC}_{\mathrm{t}}\right)$ as shown in Fig. (6 and 7). The relationships between relative total and marketable tomato yield; R.T.Yield and R.M.Yield, respectively and the soil salinity; $\mathrm{EC}_{\mathrm{e}}$ have been studied according to Maas and Hoffman model. The best correlation is shown in Fig. (6 and 7) as:

$$
\begin{array}{ll}
\text { R.T.Yield }=100-11.14\left(E C_{e}-2.97\right) & \text { for } E C_{e}>2.97, \text { with } R^{2}=0.9942 \\
\text { R.M.Yield }=100-14.693\left(E C_{e}-3.31\right) & \text { for } E C_{e}>3.31, \text { with } R^{2}=0.9869
\end{array}
$$

Where, the average yield at the irrigation water salinity of $1.25 \mathrm{dS} / \mathrm{m}$ was used as control value. Therefore, the average salinity threshold; $\mathrm{EC}_{\mathrm{t}}$ values for total and marketable fruit yield were 2.97 and $3.31 \mathrm{dS} / \mathrm{m}$, respectively.

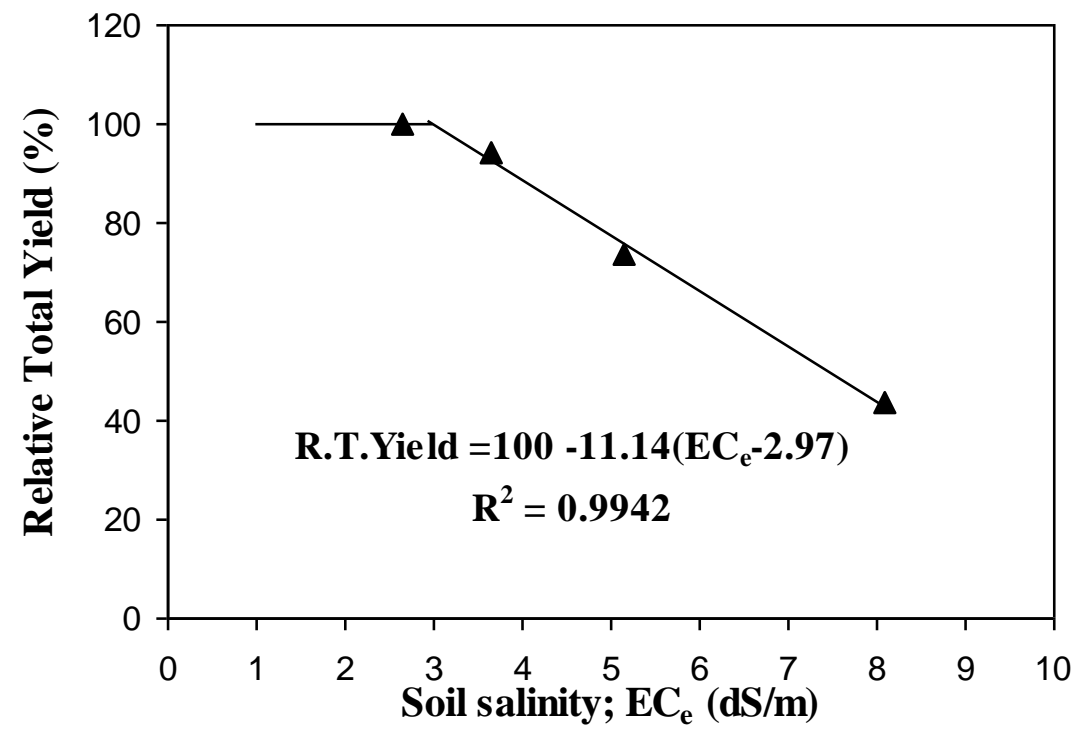

Fig. (6) Relationship between relative total tomato yield and soil salinity as expressed by Maas and Hoffman model. 


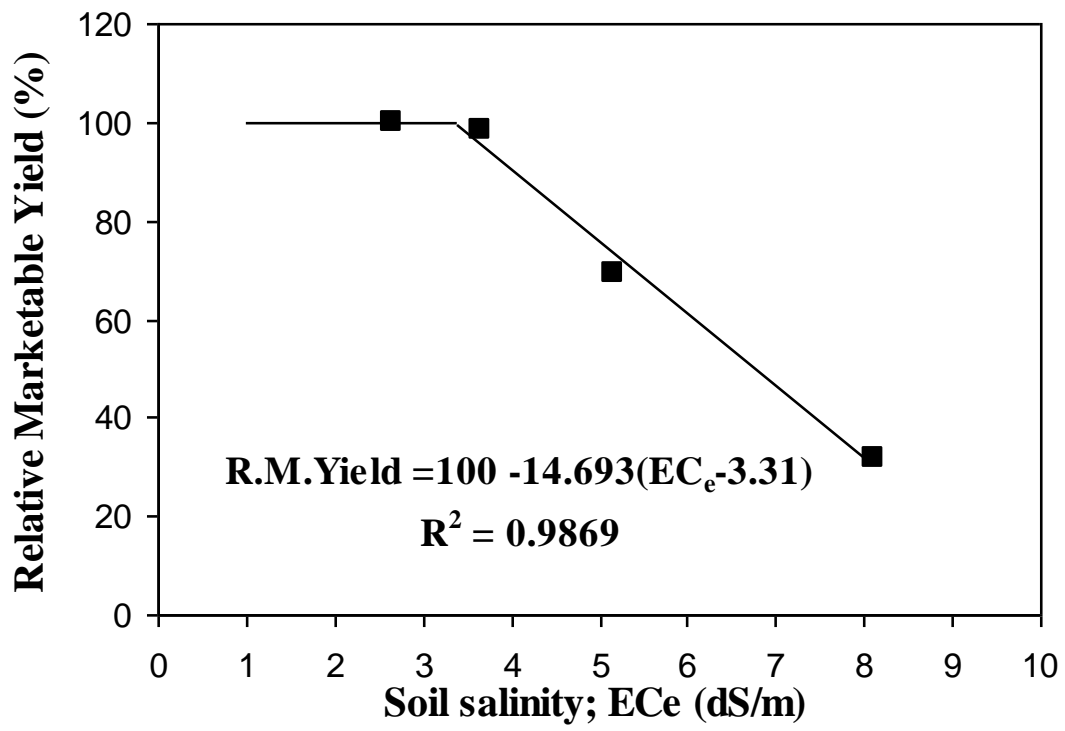

Fig. (7) Relationship between relative marketable tomato yield and soil salinity as expressed by Maas and Hoffman model.

The decreases of total and marketable yield with salinity were followed the linear slope of 11.14 and $14.693 \%$ per $\mathrm{dS} / \mathrm{m}$ after $\mathrm{EC}_{\mathrm{t}}$ values, respectively. These results are higher than those reported by Maas and Hoffman (1977), and are in accordance with those reported by Cuartero and Munoz (1999).

\section{CONCLUSIONS}

Based upon results, the following can be concluded:

1. Total yield decreased by extent of $6,26.4$ and $56.3 \%$ with increasing salinity from 1.25 to $2.5,5$ and $10 \mathrm{dS} / \mathrm{m}$.

2. Increasing the $\mathrm{K}^{+}$to 40 and $80 \mathrm{~kg} / \mathrm{fed}$ increased the average total yield by about 7.7 and $20.1 \%$, respectively. However, no significant differences were found between total yield of $\mathrm{K}_{80}$ and $\mathrm{K}_{120}$ treatments.

3. Increasing the salinity improved various aspects of fruit quality. However, salinity decreased fruit size, which is a major determinant of marketing. Also, increasing the potassium application levels affected significantly the fruit quality parameters.

4. Increasing the salinity increased the percentage of fruit affected with blossom end rot. However, increasing the potassium application levels slightly decreased this percentage. 
5. A logarithmic regression model was developed to express water consumptive use, WCU in mm as affected by irrigation water salinity; $\mathrm{EC}_{\mathrm{iw}}$ in $\mathrm{dS} / \mathrm{m}$ and potassium fertilizer levels; $\mathrm{K}^{+}$in $\mathrm{kg} \mathrm{K}_{2} \mathrm{O} / \mathrm{fed}$ as:

$$
\mathrm{WCU}=644+0.35 \mathrm{~K}^{+}-88 \ln \left(\mathrm{EC}_{\mathrm{iw}}\right)
$$

6. The relationship between water use efficiency; WUE and irrigation water use efficiency; IWUE as affected by irrigation salinity; $\mathrm{EC}_{\mathrm{iw}}$ have been expressed as

$$
\begin{aligned}
\mathrm{WUE} & =-0.302 \mathrm{EC}_{\mathrm{iw}}+7.1 \\
\mathrm{IWUE} & =-0.256 \mathrm{EC}_{\mathrm{iw}}+4.39
\end{aligned}
$$

7. The relationship between Soil salinity; $\mathrm{EC}_{\mathrm{e}}$ as affected by irrigation water salinity; $\mathrm{EC}_{\mathrm{iw}}$ has been expressed as

During growing season: $\quad \mathrm{EC}_{\mathrm{e}}=0.6132 \mathrm{EC}_{\mathrm{iw}}+2.013$

After harvesting: $\quad \mathrm{ECe}=0.7827 \mathrm{EC}_{\mathrm{iw}}+2.31$

8. The relationship between relative total and marketable tomato yield; R.T.Yield and R.M.Yield, respectively and the soil salinity; $\mathrm{EC}_{\mathrm{e}}$ has been studied according to Maas and Hoffman model as:

$$
\begin{aligned}
\text { R.T.Yield } & =100-11.14\left(\mathrm{EC}_{\mathrm{e}}-2.97\right) \\
\text { R.M.Yield } & =100-14.693\left(\mathrm{EC}_{\mathrm{e}}-3.31\right)
\end{aligned}
$$

9. The threshold; $\mathrm{EC}_{\mathrm{t}}$ values for total and marketable fruit yield were 2.97 and $3.31 \mathrm{dS} / \mathrm{m}$, respectively.

10. The decreases of total and marketable yield with $\mathrm{EC}_{\mathrm{e}}$ were followed the linear slope of 11.14 and $14.69 \%$ per $\mathrm{dS} / \mathrm{m}$ after $\mathrm{EC}_{\mathrm{t}}$, respectively.

Specific conclusion could be made as follows:

Under Siwa oasis conditions, it is advisable to maintain root zone EC at or bellow the suggested $\mathrm{EC}_{\mathrm{t}}$ of $3 \mathrm{dS} / \mathrm{m}$. this conclusion has important practical implications for the management of soil amendments, irrigation and drainage system in Siwa, where irrigation water obtained from wells, tend to have different levels of salinity.

In general, moderate salt concentration in irrigation water up to $2.5 \mathrm{dS} / \mathrm{m}$ can be used for tomato production in the specific environment considered, without major detrimental effect on tomato yield. At higher salts concentration in irrigation water, yield may be seriously reduced and considered economically unacceptable. Also, appropriate potassium application levels of $80 \mathrm{~kg} / \mathrm{fed}$ could mitigate the negative 
effects of salinity and enhance tomato growth and productivity and consequently the income.

\section{REFERENCES}

Adams, P. and L.C. Ho. (1995) Uptake and distribution of nutients in relation to tomato fruit quality. Acta. Horticulturare. 412, PP. 374-387.

Agong, S. G.; M. Yoshida; Y. Yazawa; M. Masuda.(2003). Response of tomato genotypes to induced salt stress. J.Afr.Crop Sci.11(2), PP133-142.

Al-Karaki, G. N. (2000). Growth, water use efficiency, and sodium and potassium acquisition by tomato cultivars grown under salt stress. J. Plant Nutr. 23: 1-8

Ayers, R.S, and D.W. Westcot (1985). Water quality for agriculture. FAO Irri.\& Drain. 29. Rome. 13-56.

Caruso, G. and L.Postiglione (1993). Effect of irrigation with different saline concentrations on tomato cultivars. Rivista di Agron.27(3)211-219.

CoHort Software (2005). Costat Statistical package (version 6.311), P.O.Box 1149, Berkeley, CA, 94701, USA.

Cuartero, J. and R. F. Munoz (1999). Tomato and salinity. Scientia Horticulturae ,78. PP. 83-125.

Dalton, F.N.; A. Maggio; G. Piccinni. (2001). Assessing the effect of solar radiation on plant salt tolerance as defined by the static and dynamic indices. Plant soil 229.PP189-195.

Dorias, M.; A.P. Papadopoulos; A. Gosselin. (2001). Influence of electric conductivity management on greenhouse tomato yield and fruit quality. Agronomy. 21. pp. 367-383.

Eakes, D J.; R.D. Wright and J.R. Seiler, (1991). Water relations of saliva Splendens 'Bonfire' as influenced by Potassium nutrition and moisture stress conditioning . J. Am. Soc. Hort. Sci. 116.pp. 712-715.

Favaro-Blanco, F.; M. V. Canarini (2003). Effect of nitrogen and potassium on dry matter production of tomato irrigated with saline water. ASAE Annual meeting paper number 032235.

Israelsen, O.W. and V.E. Hansen (1962). Irrigation Principles and practices 3rd Edition, John Willey and Sons. Inc. New York. P 827

Jensen, M. E. (1983). Design and operation of farm irrigation systems. ASAE. Michigan. USA. 
Lindhauer, M.G.(1985). Influence of $\mathrm{K}$ nutrition and drought on water relations and growth of sunflower. Pflanzenernaehr. Bodenk.148.654-669 Maas, E.V.; G.J. Hoffmann (1977). Crop salt tolerance current assessment. J. Irrig. Drain. Div. 103.PP. 115-134.

Maggio, A.; S. Angelino; C. Barbieri (2004). Physiological response of tomato to saline irrigation in long term salinezd soils. Eur. J. Agron.21.PP. 149-159.

Marschner, H. (1995). Mineral nutrition of higher plants. Academic press. London. P. 889.

Michael, A. (1978). Irrigation and theory practice. Vikas Pub. House PVT LTD, New Delihi.

Page, A. (1982). Methods of soil analysis. Part 2 Book series No. 9. American Soc. of Agron. And Soil Sci. Am., Madison,Wisconsin.

Petersen, K. K.; J., Willumsen; K. Kaack (1998). Composition and taste of tomatoes as affected by increased salinity and different salinity sources. J. Hort. Sci.Biotech.73, 205-215.

Peterson, M.L. (1971). US land and water resource-research needs. In Agronomy in a Changing World and research needs for the seventies. Eds. CA. Black, GE. Van Ripper, WC. Barrows and RF Holland. PP 165. Spec. Bull.19,.American Society of Agronomy, Madison, Wisconsin.

Romero-Aranda, R.;T. soria; J. J. Cuartero. (2002). Greenhouse mist improves yield of tomato plants grown under saline conditions. J. Am. Soc. Hortic. Sci. 127. pp. 644-648.

Satti, S.M.E. and M. Lopez. (1994). Effect of increasing potassium levels for alleviating sodium chloride stress on the growth and yield of tomato. Common. Soil .Sci. Plant Anal. 25 (15\&16), 2807-2823.

Snapp, S. S, and C. Shennan. (1992). Effect of salinity in root growth and death dynamic of tomato. New Phytologist.121.PP.71-79.

Soria, T. and J. Cuartero.(1997). Tomato fruit yield and water consumption with salinity water irrigation. Acta Horticulturae458,PP215-219. 


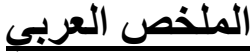

\section{تأثثير ملوحة مياه الري و مستويات التسميد البوتاسي علي الإنتاجية و الاستهلاك}

\section{المائي لمحصول الطماطم فى واحة سيوه}

عبد الحليم محمد زينون' أحمد عبد الله الثافعي` خليل عبد الحليم علام' محمود مراد

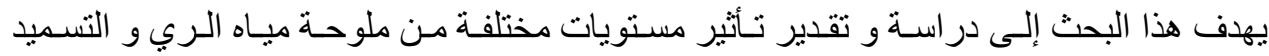

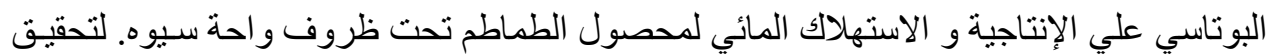

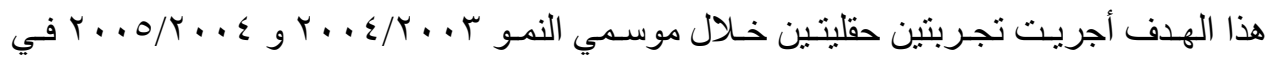

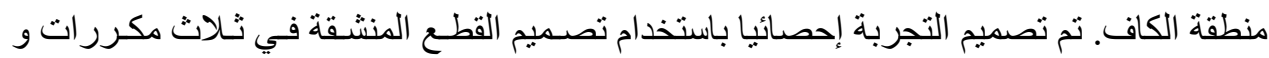

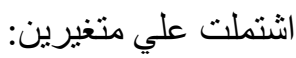

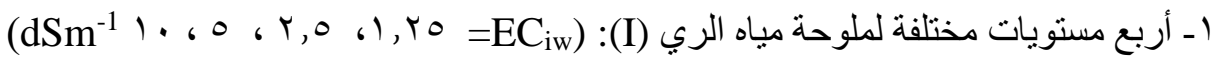

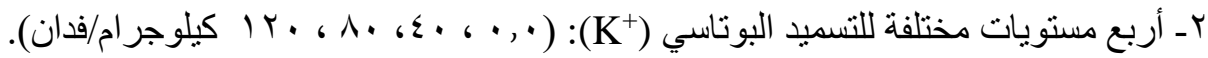

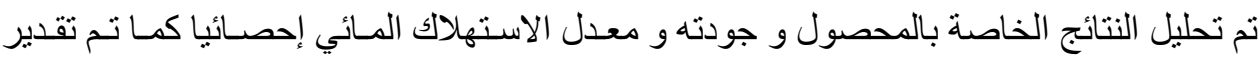

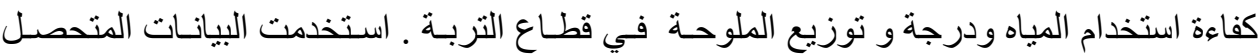

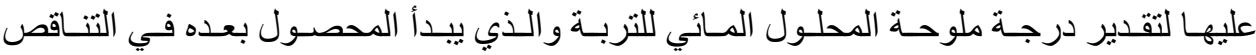
(Threshold; ECt)

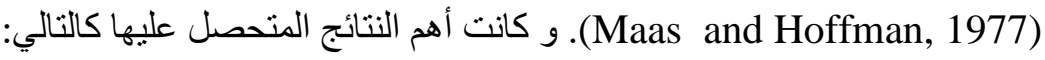

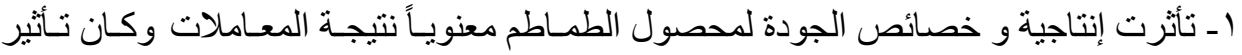

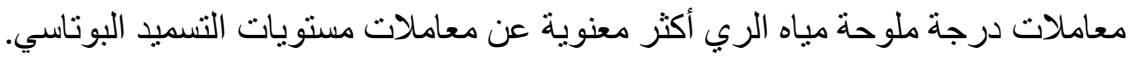

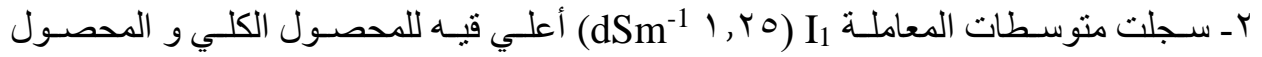

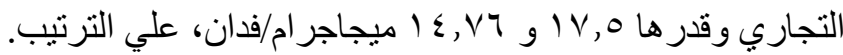

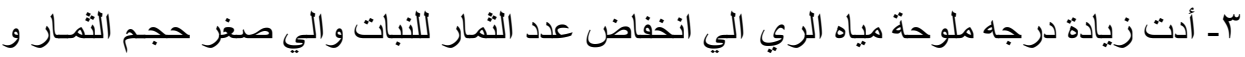

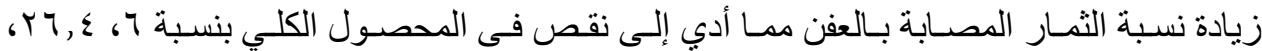

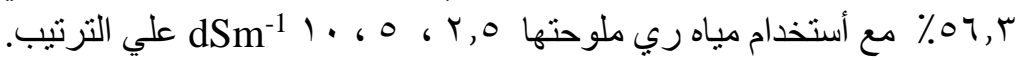

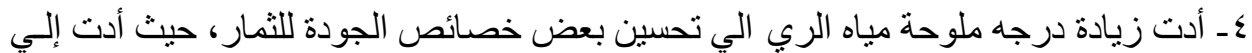

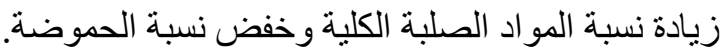

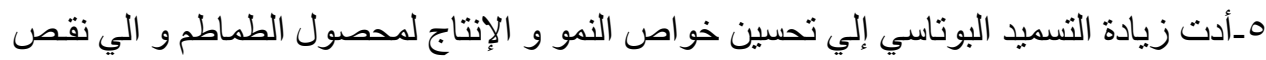

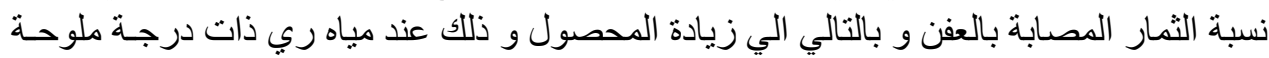

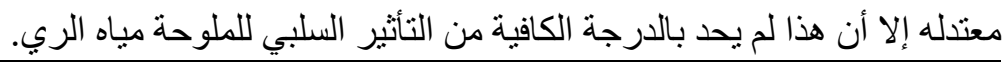
ا-باحث ـ معهد بحوث الهندسة الزر اعيةـ مركز البحوث الزر اعية.

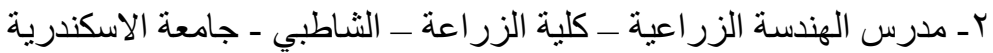

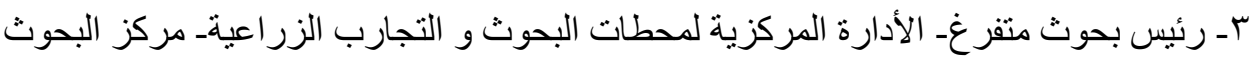

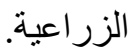


آـ أدت زيادة درجه ملوحة مياه الري الي خفض الاستهلاك المائي و الـي خفض كفـاءة استخدام

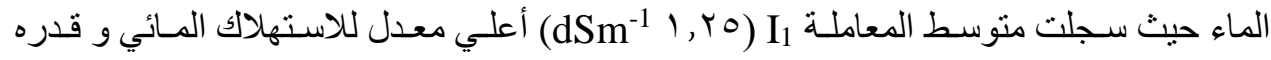

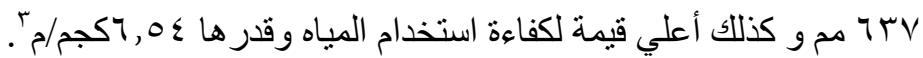

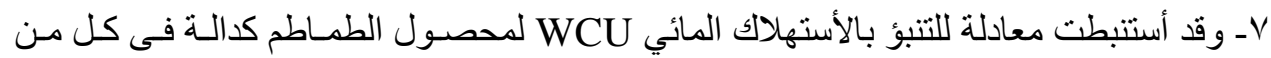

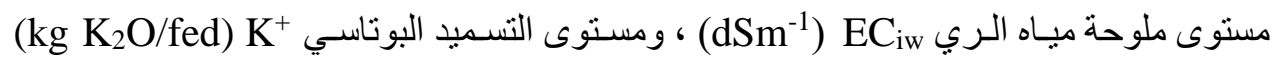
كدليل استرشادي في و احة سيوه كمايلى لرئى

$$
\mathrm{WCU}=644+0.35 \mathrm{~K}^{+}-88 \ln \left(\mathrm{EC}_{\mathrm{iw}}\right)
$$

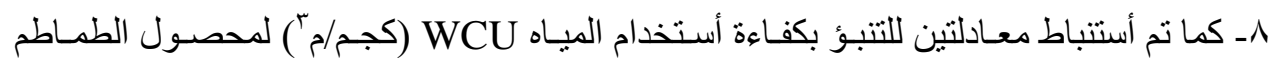

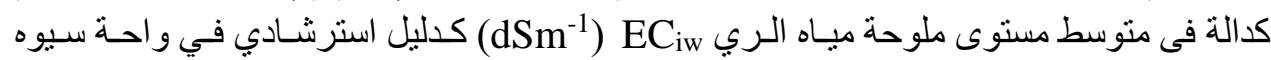

$$
\mathrm{WUE}=-0.302 \mathrm{EC}_{\mathrm{iw}}+7.1
$$

كمايلى كالى

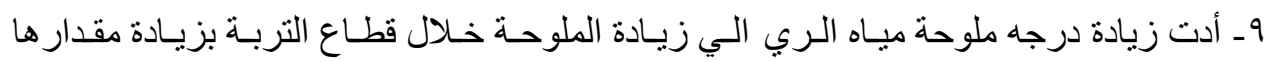

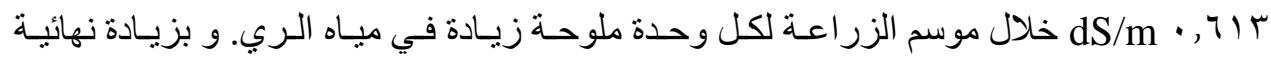

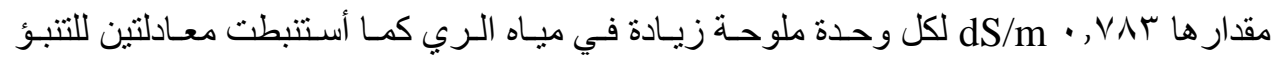

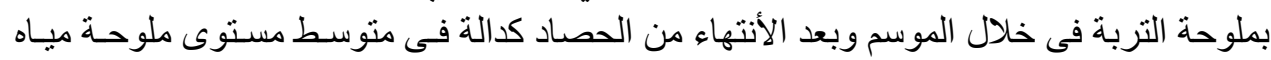

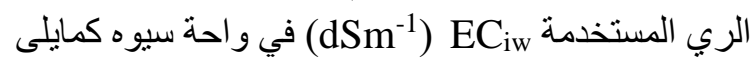

$$
\begin{aligned}
& \mathrm{EC}_{\mathrm{e}}=0.6132 \mathrm{EC}_{\mathrm{iw}}+2.013 \\
& \mathrm{EC}_{\mathrm{e}}=0.7827 \mathrm{EC}_{\mathrm{iw}}+2.31
\end{aligned}
$$

• ا ـ وبتطبيق النموذج الرياضـي لـ Maas and Hoffman لتنبؤ بكسلا مـن المحصـول الكلي

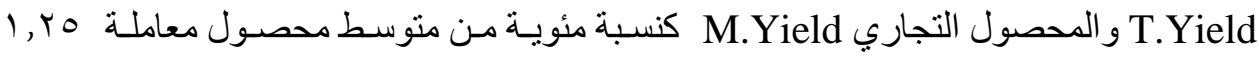

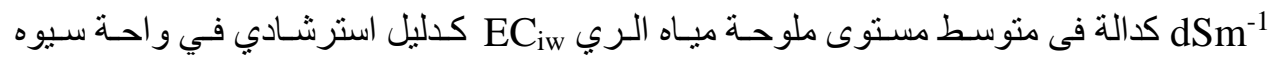

$$
\begin{aligned}
\text { R.T.Yield } & =100-11.14\left(\mathrm{EC}_{\mathrm{e}}-2.97\right) \\
\text { R.M.Yield } & =100-14.693\left(\mathrm{EC}_{\mathrm{e}}-3.31\right)
\end{aligned}
$$

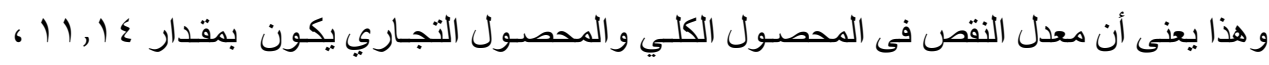

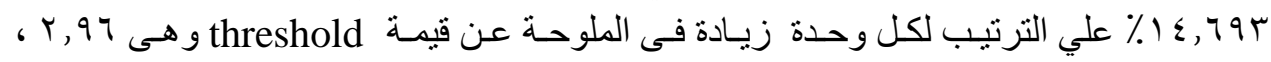

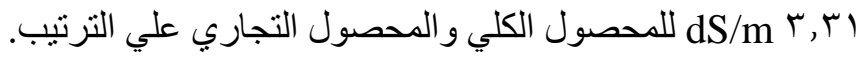

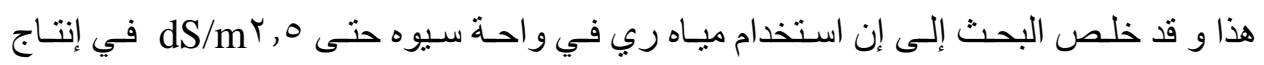

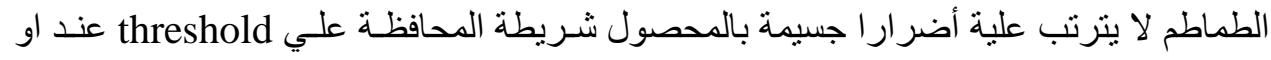

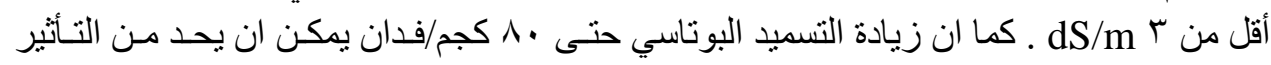

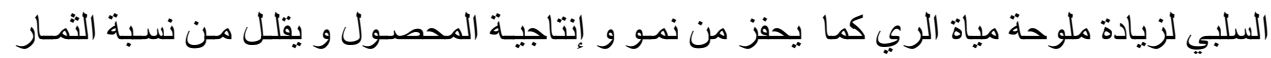
المصابة بالعفن. 